\section{Prevalence of Ocular Abnormalities in Term Infants}

\section{Term Infantlarda Oküler Anormalliklerin Prevalansı}

\section{Hatice Daldal ๑ Mustafa Türkyılmaz ๑ Oğuzhan Salış $\odot$ Musa Yiğit $\odot$ Mustafa Muhterem Ekim $\odot$}

\section{ABSTRACT}

Objective: To exhibit the results of routine ophthalmologic screening in infants between 0-1 years of age referred to the ophthalmology clinic from the departments of pediatrics and family medicine.

Method: Referred to the ophthalmology clinic between August 2014 and November 2019, 11196 eyes of 5598 term infants were retrospectively investigated in the study, and all participants were ophthalmologically examined at $1^{\text {st }}, 6^{\text {th }}$, and $12^{\text {th }}$ months of age. Infants' pupils were dilated with $0.5 \%$ tropicamide and $2.5 \%$ phenylephrine. On examination, eye and face symmetries were evaluated with inspection, fixation, and ocular tracking. Pupil responses and motility were evaluated with the light source. While the red reflex test was evaluated using a direct ophthalmoscope, fundus was assessed through an indirect ophthalmoscope.

Results: Congenital cataract (6), congenital glaucoma (3), strabismus (81), epiphora (426), non-specific retinal hemorrhages (42) and retinal pigmentation changes (10), coloboma (4) (one eyelid, four iris, one optical disc and three chorioretinal), optic disc abnormalities (3), congenital ptosis (13) (unilateral in 12 patients and bilateral in one patient), corneal dysgenesis (2) and microphthalmia (3) were determined in 11196 eyes of 5598 infants (2709 females, 2889 males).

Conclusion: Perinatal ophthalmologic screening program is likely to diagnose several diseases earlier, such as congenital cataracts, congenital glaucoma, strabismus, corneal opacities, causing vision losses in infants. Treatment options are available, and some diseases can be treated due to early intervention. Early treatment can also eliminate the problems precluding the development of complex visual ability continuing in perinatal period. Consequently, final visual acuity may be increased.

Keywords: Amblyopia, congenital cataract, congenital glaucoma, vision loss

öz

Amaç: Pediatri ve Aile Hekimliği kliniklerinden rutin göz taraması açısından yönlendirilen 0-1 yaş arası infantlardan elde edilen verileri değerlendirmek.

Yöntem: Ağustos 2014-Kasım 2019 tarihleri arasında Göz kliniğine yönlendirilen 5598 term infantın 11196 gözü retrospektif olarak çalışmaya dahil edildi. Tüm infantların 1. ay, 6. ay ve 12. ayda detaylı oftalmolojik muayeneleri yapıldı. Bebeklerin pupilleri \%0,5 tropikamid ve \%2,5 fenilefrin ile dilate edildi. Muayenede inspeksiyon ile göz ve yüz simetrisi, ışık kaynağı ile fiksasyon ve takip, pupil cevabı ve motilite, direkt oftalmoskop ile kırmızı refle testi, indirekt oftalmoskop ile fundus değerlendirildi.

Bulgular: 5598 infantın (2709 kız, 2889 erkek) 11196 gözünde, 6 konjenital katarakt, 3 konjenital glokom, 81 şaşılık, 426 epifora, 42 nonspesifik retinal hemoraji, 10 nonspesifik retinal pigmentasyon değişikliği, 4 kolobom (1 göz kapağı, 4 iris, 1 optik disk, 3 koryoretinal), 3 optik disk anomalisi, 13 konjenital pitoz (12 hasta tek taraflı, 1 hasta iki taraflı), 2 korneal disgenezi, 3 mikroftalmi tespit edildi.

Sonuç: Perinatal dönemde yapılacak oftalmik tarama programı ile bebeklerde görme azlığına neden olabilecek konjenital katarakt, konjenital glokom, şaşılık, kornea opasiteleri gibi hastalıklara erken tanı konulabilmekte, tedavisi mevcut olanlara müdahele edilebilmekte ve perinatal dönemde gelișimi devam etmekte olan kompleks görme işlevinin kazanılmasını engelleyebilecek durumlar ortadan kaldırılarak nihai görme keskinliği oranlarında artış sağlanabilmektedir.

Anahtar kelimeler: Konjenital katarakt, konjenital glokom, görme kaybı, ambliyopi
Received: 23.08 .2020

Accepted: 02.05.2021

First Publication: 20.09.2021

Cite as: Daldal H, Türkyılmaz $M$, Salış $O$, Yiğit $M$, Ekim MM. Prevalence of ocular abnormalities in term infants. izmir Dr. Behçet Uz Çocuk Hast. Dergisi. 2021;11(3):255-61.

Hatice Daldal

Uşak Üniversitesi Tıp Fakültesi, Göz Hastalıkları Anabilim Dalı,

Uşak, Türkiye

drhdaldal@hotmail.com ORCID: 0000-0002-7350-3050

M. Türkyılmaz 0000-0001-6891-9775 inegöl Devlet Hastanesi, Göz Hastalıkları, Bursa, Türkiye

O. Salış 0000-0001-7254-4988 Uşak Göz Merkezi, Göz Hastalıkları, Uşak, Türkiye

M. Yiğit 0000-0002-2761-7321 Isparta Sehir Hastanesi, Göz Hastalıkları, Isparta, Türkiye

M.M. Ekim 0000-0003-3976-609X Parkhayat Hastanesi, Göz Hastalıkları, Afyon, Türkiye 


\section{INTRODUCTION}

Ocular problems, such as poor vision in infants, should be determined passively because babies cannot express their discomfort ${ }^{(1)}$. Therefore, the American Academy of Pediatrics (AAP) recommends managing the red reflex test for newborns shortly after birth ${ }^{(1,2)}$. However, there are no convincing data on the sensitivity and false negativity rates of the red reflex test ${ }^{(3)}$. Such pathologies as congenital cataracts, corneal opacities, and retinoblastoma, which can be detected with the red reflex test, are of great importance due to potential threats to vision and even life ${ }^{(4)}$. Based on the literature, this age segment has not yet to be studied adequately, and the true prevalence of temporary or permanent ocular abnormalities remains unknown ${ }^{(3)}$.

Since 2016, ophthalmologic screening has been launched in 81 provinces of Turkey by family physicians. The present study aims to assess the prevalence of ocular abnormalities in term infants aged between 0-1 year by evaluating the results of ophthalmologic screening guided by the departments of pediatrics and family medicine. The study also intends to determine the features that may show demographic changes and compare our study results with those reported in previous studies.

\section{MATERIAL and METHOD}

In our study, 11196 eyes of 5598 infants were screened between August 2014 and November 2019 in our hospital referred to the ophthalmology clinic from the pediatric and family medicine clinics, and the data were evaluated retrospectively. Approval was obtained from the ethics committee of the institution before thestudy. Detailed ophthalmological examinations were performed at $1^{\text {st }}, 6^{\text {th }}$, and $12^{\text {th }}$ months of age by the researchers (Daldal $\mathrm{H}$, Turkyılmaz M, and Salis O). Infants' pupils were dilated with $0.5 \%$ tropicamide and $2.5 \%$ phenylephrine. In performing examinations, the eyes, eyelids, and areas around the eyelids were first inspected, and eye and face symmetries were evaluated. Then, pupil responses and ocular motilities were checked with a light source. The red reflex test was performed using a direct ophthalmoscope, and the motility was also evaluated. On the other hand, fundus examination was performed with an indirect ophthalmoscope with the help of a 20 D lens. Abnormal ocular findings were recorded, and all infants were followed up. The Statistical Package for Social Sciences for Windows 22.0 program (SPSS Inc., Chicago, IL, USA) was used to perform the statistical analyses by using descriptive statistics (percentages).

\section{RESULTS}

We included 5598 infants (2709 females, 2889 males) in our study. Abnormal ocular findings were detected in 593 (10.59\%) cases of infants involved in the study. Among the abnormal ocular findings, six congenital cataracts, three congenital glaucomas, 81 strabismus, 426 epiphoras, 42 non-specific retinal hemorrhages, 10 non-specific retinal pigmentation changes, four colobomas (as one eyelid, four iris, one optical disc, and three chorioretinal), three optic disc abnormalities, 13 congenital ptoses (unilateral in 12 patients and bilateral in one patient), two corneal dysgeneses and three microphthalmia were diagnosed (Table 1). Of 81 infants having strabismus, two and 79 were exotropia and esotropia, respectively. Those with exotropia had also cerebral palsy. Two of

Table 1. Distributions of the pathologies determined among patients

\begin{tabular}{lccc}
\hline Pathologies & $\begin{array}{c}\text { Patients } \\
\text { (n) }\end{array}$ & $\begin{array}{c}\text { Percentage } \\
\text { of all } \\
\text { infants (\%) }\end{array}$ & $\begin{array}{c}\text { Percentage of } \\
\text { determined } \\
\text { pathologies } \\
\text { (\%) }\end{array}$ \\
\hline Epiphora & 426 & 7.61 & 71.83 \\
Strabismus & 81 & 1.44 & 13.66 \\
Retinal hemorrhages & 42 & 0.75 & 7.08 \\
Congenital ptosis & 13 & 0.23 & 2.19 \\
Retinal pigmentation & 10 & 0.18 & 1.69 \\
changes & & & \\
Congenital cataracts & 6 & 0.11 & 1.01 \\
Coloboma & 4 & 0.07 & 0.67 \\
Congenital glaucomas & 3 & 0.05 & 0.51 \\
Optic disc abnormalities & 3 & 0.05 & 0.51 \\
Micro-ophthalmia & 3 & 0.05 & 0.51 \\
Corneal dysgenesis & 2 & 0.04 & 0.34 \\
& & & \\
\hline
\end{tabular}


those with esotropia had cataracts, and the other two had glaucoma, and the remaining 75 patients were with hypermetropia above three diopters. Of 593 ocular abnormalities, 115 (19.39\%) were assessed as important findings threatening the visual acuity.

\section{DISCUSSION}

Ophthalmologic screening, as well as the tests used to diagnose such diseases as phenylketonuria, hypothyroidism, and developmental hip dysplasia, is performed through the red reflex test as a newborn screening in our country. The red reflex test is an indispensable part of the neonatal examination and is used to determine many important pathologies, including cataract, corneal opacity, retinoblastoma, and retinal detachment that may be located in the visual axis ${ }^{(4)}$. In the study, the red reflex test performed in the eye without pathology is seen in Figure 1. Whether to be decreased, white, or asymmetrical, the presence of dark spots in the red reflex creates an indication for the referral of the baby to an ophthalmologist ${ }^{(5)}$.

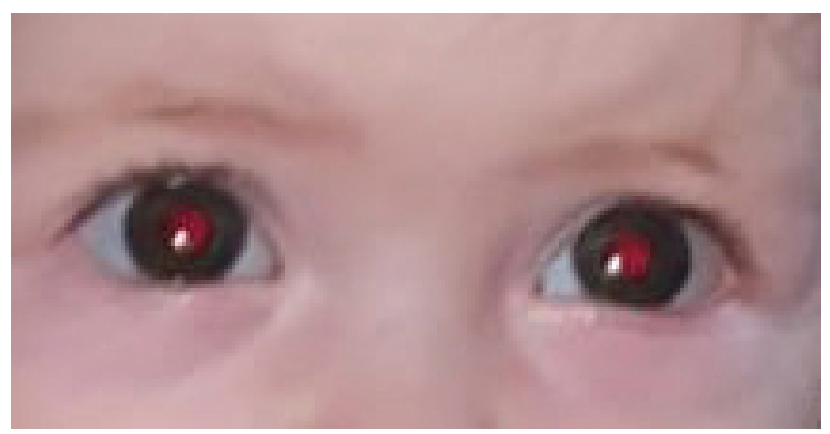

Figure 1. Red reflex test.

Ocular abnormalities can be classified into three groups. In the first group, there are non-clinical findings, such as subconjunctival hemorrhages, retinal pigmentation, and non-specific retinal hemorrhages. The second group, including findings such as the immature retina, has less clinical significance and requires the follow-up of the patients. The third and the last group consists of clinically important diseases, such as premature retinopathy, congenital cataract, congenital glaucoma, and ptosis requiring advanced treatment (1).

Retinal hemorrhages are one of the common conditions at birth and seen more commonly in vacuum-assisted births, followed by spontaneous vaginal deliveries, unlike those encountered rarely in cesarean deliveries ${ }^{(6,7)}$. Most birth-related retinal hemorrhages are intraretinal and typically resorbed within seven to 10 days, but can last up to 30 days (6-8).

In two previous studies, the most common occurring abnormality was reported as retinal hemorrhages with a prevalence of 21.52 and $20.3 \%$, respectively ${ }^{(3,9)}$. In our study, the frequency of retinal hemorrhages was determined in 42 patients $(0.75 \%)$. The low prevalence in our study was probably since our first examination at the first month of age was performed at a later period, compared to previous studies. Additionally, non-specific retinal pigmentation was observed in 10 patients $(0.18 \%)$.

In a cohort study of 4792 infants by MacEwen et al., it was found out that the prevalence of epiphora was about $20 \%$ in the first year of life, and nearly $95 \%$ of the study population showed symptoms at the age of one month ${ }^{(10)}$. In our study, epiphora was detected in $426(7.61 \%)$ infants. Three of 426 cases were due to congenital glaucoma, while the rest were due to nasolacrimal duct obstruction.

Congenital cataracts are one of the common and treatable ocular pathologies leading to childhood blindness ${ }^{(11)}$. The incidence of congenital cataracts is 1.2-6 per 10.000 cases ${ }^{(12)}$. The studies in the USA reveal that $10-38 \%$ of childhood blindness is due to congenital cataracts ${ }^{(13)}$. In our study, congenital cataracts were observed in six patients $(0.11 \%)$, and one patient with congenital cataracts had galactosemia. There was no drug use and radiation history in the mothers of infants with congenital cataracts. Additionally, the parents of another patient had also a history of consanguineous marriage. The cases with congenital cataracts are presented in Figures 2, 3, and 4 .

Among the most important reasons bringing families to the healthcare centers are leukocoria, strabismus, suspicion of visual decreasement, and 


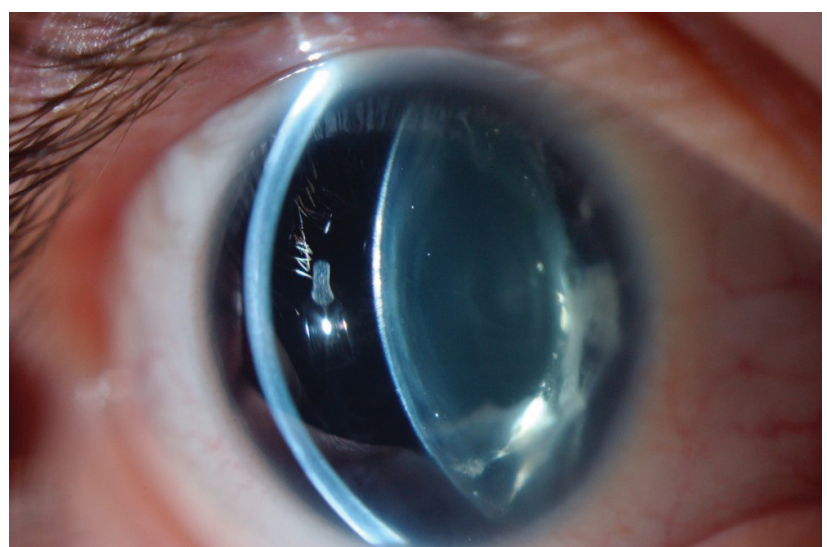

Figure 2. Congenital cataract.

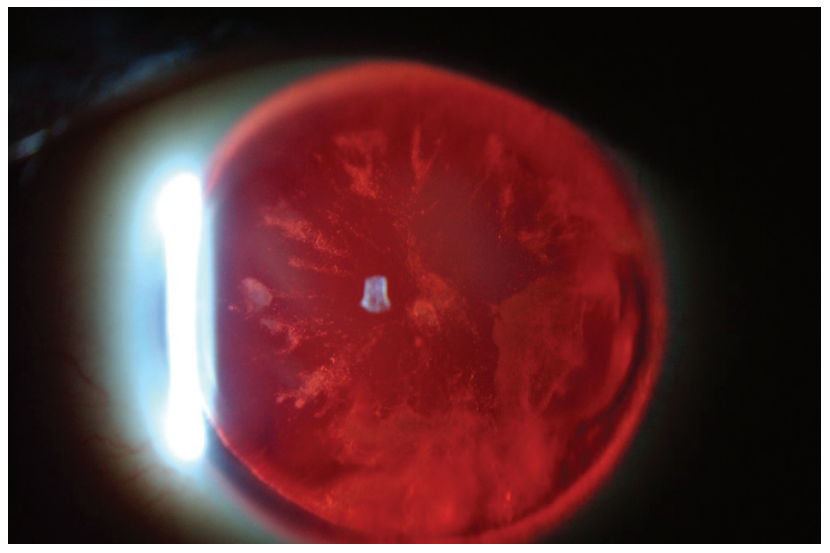

Figure 3. Congenital cataract with retroillumination.

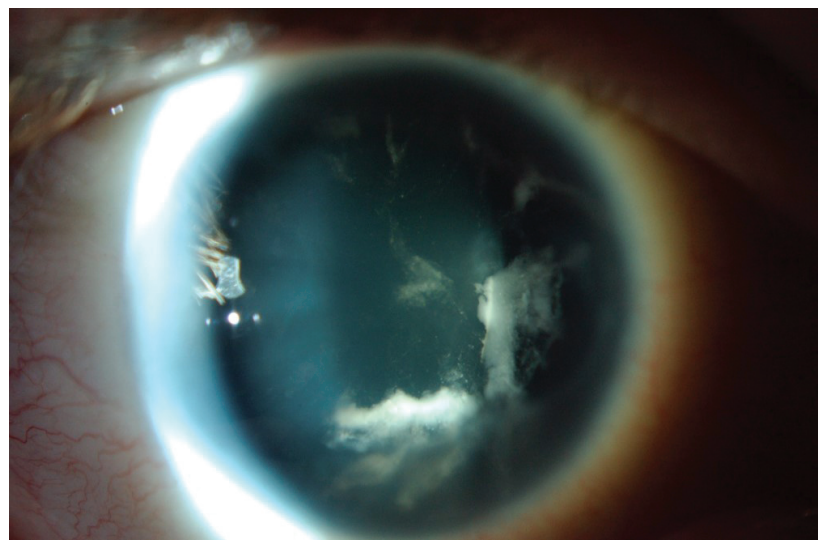

Figure 4. Congenital cataract and aniridia.

nystagmus. Visual acuity is expressed by parents as "not pursuing the objects" in the early childhood period. The cases with congenital cataracts are mostly admitted to hospitals at a late stage, and the length of time between the deterioration of the image in the retina and the elimination of the cause may lead to the irreversible deprivation of amblyopia ${ }^{(14)}$. Here, the point at which healthcare professionals should be meticulous is that pediatric cataracts may not always be seen with leukocoria. Besides ophthalmologists, therefore, family physicians and pediatricians should also examine children with the red reflex test so that cataracts can be detected more easily and treated at an early period.

Developmental glaucomas are associated with developmental ocular abnormalities at birth as a result of insufficient development of the anterior segment structures of the eyes and seen in approximately 1 out of 10000 live births ${ }^{(15)}$. Primary congenital glaucomas are rare cases and usually affect less than $0.05 \%$ of ophthalmology patients; however, the rate of blindness is high in such patients, ranging between $2-15 \%{ }^{(16)}$. Glaucoma is the second most common cause of blindness across the world and can be prevented when diagnosed and treated at an early period ${ }^{(17)}$. While the risk of congenital glaucomas does not exceed $3 \%$ in the second child of the couples if one child has glaucoma, the risk rises to $25 \%$ in the third child if there are two children with glaucoma ${ }^{(18)}$. For this reason, all family members should be questioned meticulously in terms of congenital glaucomas. When congenital glaucoma is detected in a member of the family, other children should also be examined. The probability of developing bilateral congenital glaucoma is $75 \%$, and congenital glaucomas are encountered more often among the male population (15). In our study, congenital glaucomas were determined in three $(0.05 \%)$ male cases, one was unilateral while the two were bilateral. Epiphora, photophobia, and blepharospasm are frequently seen as the first ophthalmologic symptoms in infants, and such symptoms are caused by irritation due to corneal epithelial edema due to the increased intraocular pressure. The blurred appearance of the cornea may be intermittent at the early stages and may result from tears in Descemet's membrane. The rupture of Descemet's membrane (Haab's striae) is seen in Figure 5. The abnormal growth of the globe (buphthalmos) occurs due to the increased intraocular pressure, and such a growth develops primarily at 
the corneoscleral junction. Accordingly, while the anterior chamber is deep, the anterior chamber is narrow in healthy babies ${ }^{(15)}$. In our study, all congenital glaucoma patients had epiphora and photophobia.

Family physicians or pediatricians should suspect congenital glaucomas, especially whenever buphthalmos, epiphora, photophobia, and corneal haze are encountered in screening the baby. Early diagnosis and treatment are of crucial importance as congenital glaucoma can lead to life-long blindness.

Congenital ptosis is the congenital myogenic dystrophy of the levator muscle ${ }^{(19)}$. In the general population, the incidence of amblyopia due to congenital ptosis is reported between $3-5 \%(20,21)$. Refractive errors, strabismus, and amblyopia are more common in those with congenital ptosis than those in the general population ${ }^{(20,22,23)}$. Therefore, it is important to perform examinations for strabismus and refraction to prevent the development of amblyopia in those with ptosis. In our study, congenital ptosis was detected in 13 patients $(0.23 \%)$.

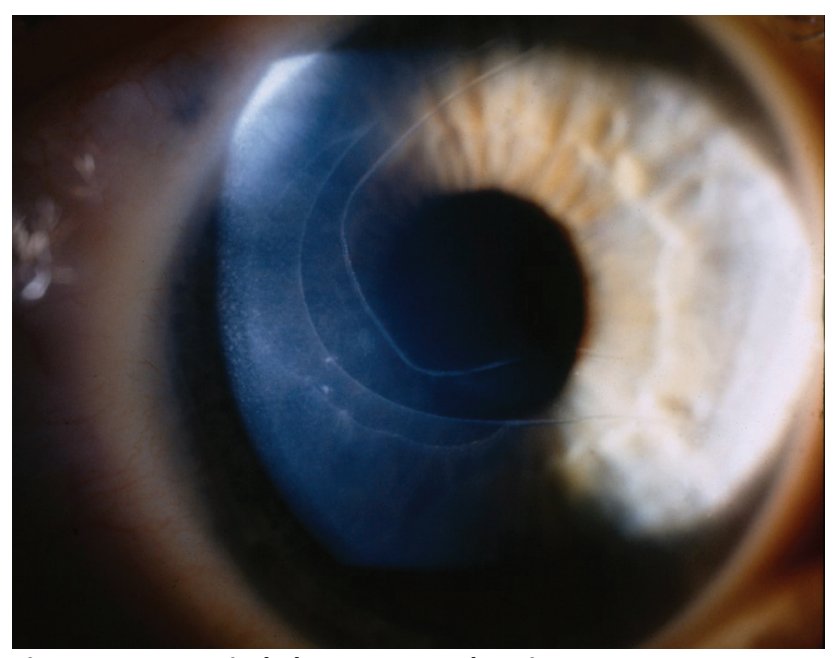

Figure 5. Congenital glaucoma, Haab striae.

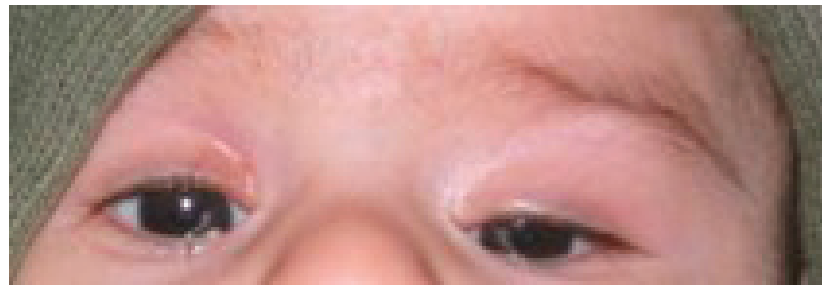

Figure 6. Congenital ptosis.
One of the patients had bilateral ptosis, while unilateral ptosis was found among the rest. Blepharophimosis syndrome was present in the bilateral case. Blepharophimosis syndrome is characterized by the narrowed horizontal palpebral opening, ptosis, epicanthus inversus, and telecanthus (24). The case of congenital ptosis is seen in Figure 6.

While strabismus is seen between 2-4\% of the general population ${ }^{(25)}$, esotropia is seen between $1-3 \%$ of the children, and infantile esotropia constitutes $28-54 \%$ of all childhood esotropias (26). Based on a recent study, esotropia was reported to affect an average of $0.25 \%$ of the society ${ }^{(27)}$. The critical period for the development of stereopsis is between the 4 th and 6 th months of age ${ }^{(28)}$. Therefore, when the exposure of the infant to stereoscopic visual stimuli stops in the first $12^{\text {th }}$ and $24^{\text {th }}$ months of life, the development of stereopsis will be defective (29). In a strabismic patient, irreversible sensory abnormalities may develop due to delayed examination. Amblyopia treatment with refractive error should be carried out at the earliest period ${ }^{(30)}$. It was suggested that if the strabismus was corrected before the 6th month of age, the sensory and motor outcomes would become superior to those operated within 18 months ${ }^{(31)}$.

In our study, strabismus was detected in 81 infants. Of 81 infants having strabismus, two and 79 were exotropia and esotropia, respectively. Those with exotropia had also cerebral palsy. Two of those with esotropia had cataracts, and the other two had glaucoma, and the remaining 75 patients were with hypermetropia above three diopters.

Ocular coloboma is a rare malformation developing due to the closing defect of the embryonic optic cleft ${ }^{(32,33)}$. Ocular colobomas may involve the iris, ciliary body, choroid, retina, and optic nerves ${ }^{\left({ }^{34}\right)}$. In population-based studies, the prevalence of coloboma is stated to vary from 3.7 to 8 per 100.000 births ${ }^{(35-37)}$. In our study, four $(0.07 \%)$ patients had colobomas (one eyelid, four iris, one optical disc, and three chorioretinal). In our study, optic disc coloboma, optic disc hypoplasia, and morning glory syndrome were also observed in three patients $(0.05 \%)$ as optic disc abnormalities. There was no history of infection, 
diabetes mellitus, or drug use in the mothers of these patients. In the light of literature, the frequency of optic nerve hypoplasias was reported between 7-10/100,000 (38,39). In our study, however, two patients had corneal dysgenesis $(0.04 \%)$; one had posterior embryotoxone, and the other had corneal opacity with iridocorneal adhesions.

The prevalence of some diseases appears to be lower than that in similar studies screening ocular conditions in infants. Such a situation can be explained by two reasons: The first is that because there are three hospitals in our region, the other infants could be diagnosed in other hospitals, and the second is that some babies are referred to ophthalmologists after 12 months of age, or at a later period.

In conclusion, such diseases as congenital cataracts, congenital glaucoma, strabismus, corneal opacities, retinal pathologies, and optic disc pathologies that may cause poor vision in infants should be diagnosed at an early period. Due to an easy test in detecting problematic eye disorders at the early stages of infants' lives, the red reflex test is of vital importance. We consider that with the early treatment, various situations that may prevent the acquisition of complex vision function in the perinatal period can be eliminated, and so an increase in final visual acuity can be obtained.

\section{Acknowledgment}

The authors would like to thank Prof. Dr. Feray Koc for her valuable contributions to Figures.

Ethics Committee Approval: Usak University Faculty of Medicine Clinical Research Ethics Committee approval was obtained (10.06.2020/232-10-06).

Conflict of Interest: The authors declare no conflict of interest.

Funding: This research received no external funding. Informed Consent: Not applicable.

\section{REFERENCES}

1. Ma Y, Deng G, Ma J, Liu J, Li S, Lu H. Universal ocular screening of 481 infants using wide-field digital imaging system. BMC Ophthalmol. 2018;18:283. https://doi.org/10.1186/s12886-018-0943-7

2. American Academy of Pediatrics, Section on Ophthalmology, American Association for Pediatric Ophthamology And Strabismus, American Academy of Ophthalmology, American Association of Certified Orthoptists. Red reflex examination in neonates, infants and children. Pediatrics. 2008;122:1401-4.

https://doi.org/10.1542/peds.2008-2624

3. Li LH, Li N, Zhao JY, Fei P, Zhang GM, Mao JB et al. Findings of perinatal ocular examination performed on 3573, healthy full-term newborns. Br J Ophthamol. 2013;97(5):588-91. https://doi.org/10.1136/bjophthalmol-2012-302539

4. Eventov-Friedman S, Leiba H, Flidel-Rimon O, Juster-Reicher A, Shinwell ES. The red reflex examination in neonates: an efficient tool for early diagnosis of congenital ocular diseases. Isr Med Assoc J. 2010;12 (5):259-61.

5. McLaughlin C, Levin AV. The red reflex. Pediatr Emerg Care. 2006;22(2):137-40.

https://doi.org/10.1097/01.pec.0000199567.87134.81

6. Giles CL. Retinal hemorrhage in the newborn. Am J Ophthalmol. 1960;49:1005-11.

https://doi.org/10.1016/0002-9394(60)91824-9

7. Emerson MV, Pieramici DJ, Stoessel KM, Berreen JP, Gariano RF. Incidence and rate of disappearance of retinal hemorrhage in newborns. Ophthalmology. 2001;108:36-9. https://doi.org/10.1016/S0161-6420(00)00474-7

8. Jain IS, Singh YP, Grupta SL, Gupta A. Ocular hazards during birth. J Pediatr Ophthalmol Strabismus. 1980;17(1):14-6. https://doi.org/10.3928/0191-3913-19800101-04

9. Callaway NF, Ludwig CA, Blumenkranz MS, Jones JM, Fredrick DR, Moshfeghi DM. Retinal and optic nerve hemorrhages in the newborn infant: one-year results of the newborn eye screen test study. Ophthalmology. 2016;123:1043-52. https://doi.org/10.1016/j.ophtha.2016.01.004

10. Macewen CJ, Young JDH. Epiphora during the first year of life. Eye (Lond). 1991;5:596-600. https://doi.org/10.1038/eye.1991.103

11. Layden WE: Cataracts and Glaucoma, Clinical Ophthalmology, Harper and Row Publishers Inc, Philadelphia 1984 p. 5-17.

12. Koller HP, Fecarotta CM. Maguire JI, Murchison AP, Jaeger EA. Congenital and Pediatric Cataracts. Wills Eyes Institute 5 Minute Ophthalmology Consult. Philadelphia 2012 p. 188-9.

13. Grignolo A, Rivara A: Biometry of the human eye from the sixth month of pregnancy to the tenth year of life, in Vanysek J (eds): Diagnostica Ultrasonica in Ophthalmologia. Brno, Universita J E Purkyne 1968 p. 251.

14. Zwaan J, Mullaney PB, Awad A, Al-Mesfer S, Wheeler DT. Pediatric intaocular lens implantation: Ophthalmol. 1998;105:112-9. https://doi.org/10.1016/S0161-6420(98)91568-8

15. Tamcelik N. Primary Congenital Glaucoma. Ozcetin H. Glaucoma Diagnosis, Types, and Treatment. 2009 p. 350-7.

16. CV Mosby, St Louis. Normal and abnormal development, Congenital deformities. Duke-Elder S (ed). System of Opthalmology. 1969 p.720.

17. Resnikoff S, Pascolini D, Etya'ale D, Kocur I, Pararajasegaram $R$, Pokharel GP, et al. Global data on visual impairment in the year 2002. Bull World Health Organ. 2004;82:844-51.

18. Gurbuz Koz O. Congenital Glaucoma: Terminology, Classification, Pathogenesis. Glo-Kat. 2011;6:Special Issue:3540.

19. Berke RN, Wadsworth J. Histopathology of levator muscle in congenital and acquired ptosis. Arch Ophthalmol. 1955;53:413-28. 
https://doi.org/10.1001/archopht.1955.00930010415017

20. Hornblass A, Kass LG, Ziffer AJ. Amblyopia in congenital ptosis. Ophthalmic Surg. 1995;26:334-7. https://doi.org/10.3928/1542-8877-19950701-14

21. Downig AH. Ocular defects in 60.000 selectees. Arch Ophthalmol. 1945;33:137-43. https://doi.org/10.1001/archopht.1945.00890140057006

22. Merriam WW, Ellis FD, Helveston EM. Congenital blepharoptosis, anisometropia and amblyopia. Am J Ophthalmol. 1980;89:401-7.

https://doi.org/10.1016/0002-9394(80)90011-2

23. Anderson RL, Baumgartner SA. Strabismus in ptosis. Arch Ophtalmol. 1980;98:1062-7. https://doi.org/10.1001/archopht.1980.01020031052008

24. Beaconsfield M, Walker JW, Collin JR. Visual development in the blepharophimosis syndrome. $\mathrm{Br} J$ Ophthalmol. 1991;75:746-8. https://doi.org/10.1136/bjo.75.12.746

25. Abrahamsson M, Magnusson G, Sjöstrand J. Inheritance of strabismus and the gain of using heredity to determine populations at risk of developing strabismus. Acta Ophthalmol Scand. 1999;77:653. https://doi.org/10.1034/j.1600-0420.1999.770609.x

26. Williams C, Northstone K, Howard M, Harvey I, Harrad RA, Sparrow JM. Prevalence and risk factors for common vision problems in children: data from the ALSPAC study. $\mathrm{Br} \mathrm{J}$ Ophthalmol. 2008;92:959-64. https://doi.org/10.1136/bjo.2007.134700

27. Louwagie CR, Diehl NN, Greenberg AE, Mohney BG. Is the Incidence of Infantile Esotropia Declining? A PopulationBased Study From Olmsted County, Minnesota, 1965 to 1994. Arch Ophthalmol. 2009;127(2) :200-3. https://doi.org/10.1001/archophthalmol.2008.568

28. Birch EE, Wang J. Stereoacuity Outcomes Following Treatment of Infantile and Accommodative Esotropia. Optom Vis Sci. 2009; 86(6):647-52. https://doi.org/10.1097/OPX.0b013e3181a6168d

29. Birch EE, Fawcett S, Stager DR. Why does early surgical alignment improve stereoacuity outcomes in infantile esotropia? J AAPOS. 2000;4:10-4. https://doi.org/10.1016/\$1091-8531(00)90005-3

30. Costenbader FD. Infantile esotropia. Trans Am Ophthalmol Soc. 1961;59:397-429.

31. Helveston EM, Ellis FD, Plager DA, Miller KK. Early surgery for essential infantile esotropia.J Pediatr Ophthalmol Strabismus. 1990;27:115-8. https://doi.org/10.3928/0191-3913-19900501-03

32. Pagon RA. Ocular coloboma. Surv Ophthalmol. 1981;25:22336. https://doi.org/10.1016/0039-6257(81)90092-8

33. Stoll C, Alembik Y, Dott B, Roth MP. Epidemiology of congenital eye malformations in 131760 consecutive births. Ophthalmic Paediatr Genet. 1992;13:179-86. https://doi.org/10.3109/13816819209046487

34. Wang $\mathrm{P}$, Liang $\mathrm{X}, \mathrm{Yi}$ J, Zhang $\mathrm{Q}$. Novel SOX2 mutation associated with ocular coloboma in a Chinese Family. Arch Ophthalmol. 2008;126:709-13. https://doi.org/10.1001/archopht.126.5.709

35. Vogt G, Szunyogh M, Czeizel AE. Birth characteristics of different ocular congenital abnormalities in Hungary. Ophthalmic Epidemiol. 2006;13(3):159-66. https://doi.org/10.1080/09286580600599465

36. Morrison D, FitzPatrick D, Hanson I, Williamson K, van Heyningen V, Fleck B, et al. National study of microphthalmia, anophthalmia, and coloboma (MAC) in Scotland: investigation of genetic aetiology. J Med Genet. 2002;39(1):16-22. https://doi.org/10.1136/jmg.39.1.16

37. Bermejo E, Martínez-Frías ML. Congenital eye malformations: clinical-epidemiological analysis of 1,124,654 consecutive births in Spain. Am J Med Genet. 1998;75(5):497-504. h t t p s: / / d o i.org / 10.1002 / ( S I CI) 1096 8628(19980217)75:5<497::AID-AJMG8>3.0.CO;2-K

38. Blohmé J, Bengtsson-Stigmar E, Tornqvist K. Visually impaired Swedish children. Longitudinal comparisons 1980-1999. Acta Ophthalmol Scand. 2000;78:416-20. https://doi.org/10.1034/j.1600-0420.2000.078004416.x

39. Blohmé J, Tornqvist K. Visual impairment in Swedish children. III. Diagnoses. Acta Ophthalmol Scand. 1997;75:681-7. https://doi.org/10.1111/j.1600-0420.1997.tb00630.x 